\title{
ASIA MAJOR
}

A Review devoted to the study of the Languages, Arts and Civilizations of the Far East and Central Asia

EDITED BY

B. SCHINDLER, Ph.D.

EDITORIAL BOARD

Professor H. H. Dubs, Ph.D., University of Oxford

Professor E. Edwards, M.A., D.Lit., University of London

Professor G. Haloun, M.A., Ph.D., University of Cambridge

Professor W. Slmon, Ph.D., D.Lit., University of London

Dr. Arthur Waley, M.A., LL.D., F.B.A.

ASIA MAJOR IS ABOUT TO RESUME PUBLICATION

and Vol. I, Part 1, of the New Series will be published January, 1949

Vol. I, Part 1 includes the following articles:

W. Simon: The Range of Sound Alternations in Tibetan Word Families

A. C. Moule: Ginkgo Biloba or 銀 杏 Yin Hsing

H. W. BAILEY : A Khotanese Text concerning the Turks in Kantsou

J. K. Rideout: The Rise of the Eunuchs in the T'ang Dynasty
W. Perceval Yetts: A Datable Shang-Yin Inscription

A. Waley: Notes on Mencius

J. R. MCEwaN : Motoori's View of Phonetics and Linguistics in his Mojigoe no Kanazukai and Kanji San On Kö

G. Haloun : The Liang-Chou Rebellion, A.D. 184-221

Two short grammatical notes by the Editor and some reviews of books

Vol. I, Part 2, will include amongst others, articles by C. A. Hennig, The Name of the "Tokharian" Language; A. H. Francke, gZer Myig, i.e. Rays from the Eyes of the Svastika, a Precious Summary of the World. Book VIl. Translated from the Tibetan; E. J. A. Henderson, Certain Prosodic Features of Siamese ; E. Edwards, Liu Tsung-yuan and the Earliest Essays on Scenery ; B. Schindler, On the Passive Voice in Chinese ; G. Haloun, The Staël-Holstein Scroll.

$£ 25 s .0 d$. per volume

Single Copies 25s.

\section{TA YLOR'S FOREIGN PRESS}

41 GREAT RUSSELL STREET, LONDON, W.C. 1 


\section{Oriental Books, Indian and Persian Art, MSS., Bronzes, etc.}

\section{INSPECT OUR}

\section{GALLERIES OF ORIENTAL ART}

All the books prescribed for students at the School of Oriental Studies and the Universities are kept in stock.

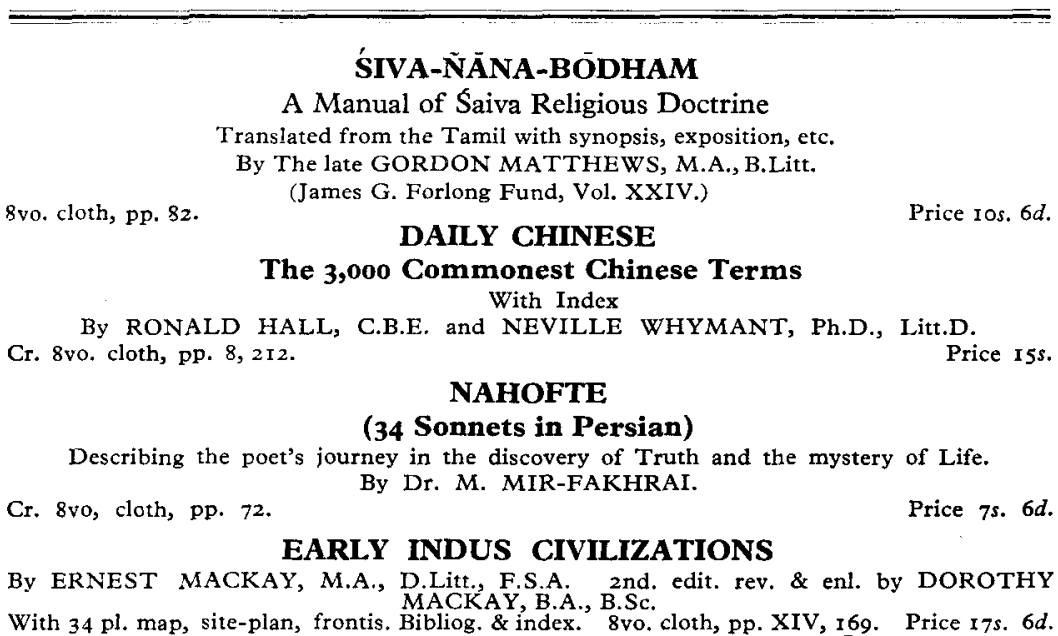

In st. prov.

\section{AL FAKHRI}

Al Fakhri : On the Systems of Government and the Moslem Dynasties. Composed by Muhammad Son of 'Ali, Son of Tabataba, Known as the Rapid Talker, May God Have Mercy on Him.

8 vo. cloth, pp. vii, 326 .

Translated by C. E. J. WHITTING

\section{HANDBOOK OF DIPLOMATIC AND POLITICAL ARABIC}

By BERNARD LEWIS, Ph.D.

8vo. st. ppr. cov. 6,73.

Price $4 s .6 d$.

\section{INTRODUCTION TO TELUGU GRAMMAR}

8vo, lp. cloth, pp. 3 I.

By ALFRED MASTER, C.I.E., M.A.

Price 5s.

\section{ART AND THOUGHT}

A Volume in Honour of the late Dr. ANANDA $K$. COOMARASWAMY Edited by $K$. BHARATHA IYER

Forty authoritative and original contributions by the leading scholars, art-critics, and thinkers of East and West on the art and thought of the great traditional cultures of India, China, Tibet, Babylonia, Persia, and Europe. The Hindu, Buddhist, Jain, Christian, and Islamic Civilizations in all their varied aspects.

Imp. 8vo, cloth bound, pp. XVI, 259. With $5 I$ plates and other illustrations in the text. Price $£ 33$ s.

\section{LUZAC

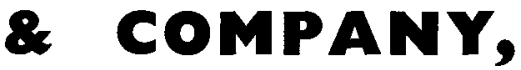 \\ LTD.}

\section{Oriental and Foreign Booksellers.}

Agents to the Royal Asiatic Society; School of Oriental and African Studies, London; Royal Asiatic Society of Bengal, Calcutta; Bihar and Orissa Research Society, India; Siam Society; Bangkok; University of Calcutta, etc.

\section{Great Russell Street, London, W.C. I}

(Opposite the British Museum.) 


\section{$\boldsymbol{R E A D}$}

\section{The Muslim World}

Continuing The Moslem World

A Quarterly Review of History, Culture, Religions and the Christian Mission in Islamdom

Published by the Hartford Seminary Foundation EDITOR :

\section{Edwin E. Calverley}

\section{CONTENTS FOR APRIL, 1949}

HOPE FOR RELIGIOUS LIBERTY IN
ISLAM -
- $\quad$ -
W. N. Wysham

WOMEN OF THE WESTERN

SAHARA - - - A. Dorothy Watson

ARCHTTECTURE OF THE MUGHAL

EMPERORS - - $\quad$ - Edward F. Smith

THE HISTORY OF ISLAM IN INDIA II James D. Brown THE RELIGIOUS AND POLITICAL DEVELOPMENT

OF MUHAMMAD I - $\quad$ E. Hammershaimb

THE QUR'ĀN AND ISLAM - _ - William Thomson

Subscriptions will be received at the following offices :

The Muslim World, Hartford Seminary

Foundation, Hartford 5, Connecticut, U.S.A.

Marshall, Morgan \& Scott, 33 Ludgate Hill,

London, E.C. 4

SUBSCRIPTION PRICES :

$\$ 2.00$ (8 shillings) single yearly subscription.

$\$ .50$ (2 shillings) single copy. 


\section{ROYAL ASIATIC SOCIETY'S PUBLICATIONS}

Sole Agent : Messrs. LuzAC \& Co., 46 Great Russell Street, W.C. 1

\section{MONOGRAPHS Vols. XXII-XXIV}

Jews in the Economic and Political Life of Mediaeval Islam. By W. J.

FisCHel. 1937. Price 12s. 6 d.

The Rise of the Ottoman Empire. By Paul WitTek. 1939. $2 s .6 d$.

The Magadhas in Ancient India. By B. C. LAw. 1946. $7 s .6 d$.

\section{PRIZE PUBLICATION FUND Vols. XIV-XVIII}

Women in the Aiyam al-Arab. By I. LICHTENSTÄDTER. 1935. $5 s$.

Early Samkhya. By E. H. Johnston. 1937. 5s.

The Early Iranian Calendars. By S. H. TAQIZADEH. 1938. $4 s$.

Feudalism in Egypt, Syria, Palestine and The Lebanon, 1250-1900. By A. N. Poliak. 1939. 5s.

Adventurers in Siam in XVII Century. By E. W. Hutchinson. $12 s .6 d$.

\section{ORIENTAL TRANSLATION FUND Vols. XXXII-XXXIV}

Tibetan Literary Texts and Documents from Chinese Turkestan. Vol. I.

By Prof. F. W. Thomas. 1935. 20s. (Vol. II in the Press.)

Purusa Parīkșā or Test of a Man. By G. A. Grierson. 1935. 12s. $6 d$.

Tracts on Listening to Music. By J. RoBson. 1938. 12s. $6 d$.

\section{JAMES G. FORLONG FUND Vols. XIV-XXIII}

Balti Grammar. By A. F. C. ReAD, Central Asian Mission. 1934. 8s. $6 d$. Kashmiri Sounds. By T. Grahame Bailey. 1937. 10s. $6 d$.

Three Persian Dialects. By AnN K. S. Lambton. 1938. 7s. $6 d$.

Marriage in Early Islam. By G. H. STERN. 1939. 10s. $6 d$.

A Dictionary of the Language of Bugotu. Compiled by W. G. Ivens, Litt.D. $1940.7 s .6 d$.

A Translation of the Kharoșthi Documents from Chinese Turkestan. By T. Burrow. 1940. 7s. 6 d.

Sogdica. By W. B. Henning. 1940. 7s. 6 d.

Sharaf al-Zamān Takir Marvazi on China, the Turks, and India. By V. MINORSKY. 1942. 15s.

Muslim Theology. By A. S. Tritton. 1947. 12s. $6 d$.

Śiva-Ñ̄ana-Bōdham. A manual of Śaiva Religious Doctrine. By Gordon Matthews. 1948. 10s. $6 d$.

Catalogue of Printed Books published before 1932 in the Library of the Royal Ásiatic Society. $£ 33$ s. 


\section{ROYAL ASIATIC SOCIETY}

56 Queen Anne Street, W.1 (Tel.: Welbeck 8944)

The annual subscription is :-

(a) $£ 33 s$. for Fellows, whether resident in Great Britain or abroad (except ministers of religion, teachers of Oriental subjects, and officials of museums and libraries, whose subscriptions the Council may reduce to $£ 22 s$.);

(b) £2 $2 s$. for Members, living in Great Britain outside the London postal area;

(c) $£ 110$ s. for Members abroad and for Library Associates;

(d) 10s. for Student Associates.

Fellows and Members receive the Society's Journal post free and enjoy the use of its library and admission to lectures and meetings.

Libraries and non-members can obtain the Journal post free by payment of $£ 28$ s. a year in advance to the Secretary. The price of each separate part is $15 s$.

The Society's Journal contains original articles on the archæology, art, history, language, literature, beliefs and customs of the East.

Acknowledgment of books and pamphlets presented to the Society is made in the Journal, which reviews the more important but cannot return those not reviewed. 